\title{
Sorption of OXadiazon in Soils Cultivated in the BRazilian Cerrado ${ }^{1}$
}

\author{
Sorção do Oxadiazon em Solos Cultivados no Cerrado Brasileiro
}

\author{
MENDES, K.F. ${ }^{2}$, REIS, M.R. ${ }^{3}$, PEREIRA, A.A. ${ }^{3}$, NUNES, A.R.S. ${ }^{3}$, SANTOS, C.E.M. ${ }^{4}$, and \\ ASSIS, A.C.L.P. ${ }^{3}$
}

\begin{abstract}
The objective of this study was to evaluate oxadiazon sorption in different soils of the Brazilian Cerrado, highlighting the correlations of lethal doses of this herbicide capable of inhibiting $50 \%$ of the dry matter accumulation of the bio-indicator (LD50) among the chemical characteristics of the soil and its direct and indirect effects. The experiment was carried out in a greenhouse in a randomized block design and four repetitions. Each experimental unit consisted of a pot with increasing rates of oxadiazon and oat (Avena sativa), as the bio-indicator species. For sorption evaluation, washed sand and 22 soils (substrates) from Cerrado Brazilian's Alliaceae cultivated areas were used. LD50 and sorption ratio (SR) $=$ [(LD50soil - LD50sand) / LD50sand] to the substrates were determined. Pearson correlation analysis was performed between the chemical characteristics of the substrates and the LD50 of oxadiazon. A path analysis was quantified, to deploy only the significant correlations estimated in direct and indirect effects of the characters on LD50, which is a basic variable. A more pronounced LD50 (528.09 $\left.\mathrm{g} \mathrm{ha}^{-1}\right)$ for the Cerrado soil sample resulted in higher SR (> 53.00), while in the washed sand substrate, LD50 corresponded only to $9.74 \mathrm{~g} \mathrm{ha}^{-1}$ of the oxadiazon (available in soil). It was concluded that oxadiazon sorption is influenced by the chemical characteristics of the soils, highlighting the correlation with $\mathrm{pH}\left(\mathrm{CaCl}_{2}\right)$, magnesium content, aluminum, organic matter, organic carbon, and aluminum saturation.
\end{abstract}

Keywords: bioassay, neutral herbicide, organic matter.

RESUMO - Objetivou-se neste estudo avaliar a sorção do oxadiazon em diferentes solos do Cerrado Brasileiro, destacando as correlações da dose letal do herbicida capaz de inibir 50\% do acúmulo da massa seca do bioindicador (DL50) entre as características químicas do solo e seus efeitos diretos e indiretos. O experimento foi realizado em casa de vegetação, com delineamento em blocos casualizados com quatro repetições. Cada unidade experimental foi constituída de um vaso com doses crescentes do oxadiazon; utilizou-se a aveia (Avena sativa) como espécie bioindicadora. Na avaliação da sorção, foram utilizados areia lavada e 22 solos (substratos) provenientes de áreas cultivadas com Alliaceae no cerrado Brasileiro. Foram determinadas a DL50 e a relação de sorção $(R S)=[(D L 50$ solo DL50areia)/DL50areia], para os substratos. Posteriormente, análise de correlação de Pearson foi realizada entre as caracteristicas quimicas dos substratos e a DL50 do oxadiazon. Foi quantificada ainda a análise de trilha, a fim de desdobrar somente as correlações significativas estimadas em efeitos diretos e indiretos de caracteres sobre a DL50, que é uma variável básica. A DL50 mais expressiva (528,09 $\left.\mathrm{g} \mathrm{ha}^{-1}\right)$ para uma das amostras de solo de cerrado resultou em maior $R S(>53,00)$. Já no substrato de areia lavada, a DL50 foi de apenas 9,74 $\mathrm{g} \mathrm{ha-1}$ do oxadiazon (disponivel no solo). Conclui-se que a sorção do oxadiazon é influenciada pelas características quimicas dos solos, ressaltando a correlação com o $\mathrm{pH}\left(\mathrm{CaCl}_{2}\right)$, teor de magnésio, alumínio, matéria orgânica, carbono orgânico e a saturação por aluminio.

Palavras-chave: bioensaio, herbicida neutro, matéria orgânica.

Recebido para publicação em 23.7.2013 e aprovado em 5.12.2013.

Centro de Energia Nuclear na Agricultura-CENA, campus ESALQ, Piracicaba, SP, Brazil. <kassio_mendes_06@hotmail.com>;

Universidade Federal de Viçosa, Rio Paranaíba-MG, Brasil; ${ }^{4}$ Universidade Federal de Viçosa, Viçosa-MG, Brasil.

Planta Daninha, Viçosa-MG, v. 32, n. 1, p. 215-225, 2014 


\section{INTRODUCTION}

The sorption process controls the transport, persistence, bioavailability and fate of herbicides in the soil (Tao \& Tang, 2004). This process comprises passing solute (herbicide) of the aqueous phase to the surface of a solid substance (soil), by means of physical or chemical interactions (Estévez et al., 2008). From the kinetic point of view, the sorption of herbicides presents a rapid initial step, responsible for much of the overall sorption, followed by a slower phase, tending to final equilibrium between the sorbed phase and the remaining in solution (Oliveira et al., 2005; Estévez et al., 2008).

The sorption varies with soil properties, such as content of clay, organic matter, $\mathrm{Ca}^{2+}$, cation exchange capacity and surface area (Burns et al., 2006). The highest content of organic matter in the soil promotes increased sorption herbicide; therefore, the herbicidal activity decreases with increasing content of soil organic carbon (Ben-Hur et al., 2003). There is an increasing application of agroindustrial wastes rich in organic matter in agricultural soils, due to the low cost or infeasibility of alternatives, such as green manure or animal manure (Delgado-Moreno $\&$ Peña, 2008). Strong positive correlation has been reported between the organic carbon content of the soil and the sorption of herbicides (Albarrán et al., 2003; Ahangar et al., 2008), in which leaching of these molecules could be reduced by application of organic compounds.

Although the increase of the amount of organic matter in the soil generally increasing absorption of herbicides and reducing leaching, it may also, in parallel, increase the persistence of the herbicide, and therefore increase the risk of water contamination over time (Cabrera et al., 2008). Moreover, the efficiency of the interaction of the soil organic matter with herbicides is influenced by its molecular configuration, polarity and size, as well as by its chemical characteristics and the nature of the soil (Celis et al., 1998).

The sorption of neutral or nonionic compounds such as oxadiazon has been extensively studied and appears to be dependent on the molecular nature of the organic matter contained in the soil (Estévez et al., 2008).

Oxadiazon is oxidase protoporphyrinogen inhibitor (PROTOX), which operates in the accumulation of protoporphyrinogen in the chloroplast, diffusing into the cytosol, the oxidation occurring at protoporphyrin IX (precursors of chlorophyll), which is a photodynamic pigment. Oxadiazon applied in cotyledons of Cucumis sativus promoted disruption of cell membranes after one hour of exposure to light (Duke et al., 1989), rapidly dehydrating and disintegrating the organelles cells.

The evaluation of sorption of herbicides have been assessed by different methods, such as the bioassay (Freitas et al., 1998; Firmino et al., 2008), which is simple, rapid and lowcost. Alternatively, test plants (bio-indicator) are used, which exhibit high sensitivity to the herbicide of interest (Eliason et al., 2004; Szmigielski et al., 2009). This technique is more affordable than the chromatographic quantitative methods. In view of the above, studies involving the interaction between herbicides and soil components (Celano et al., 2008; Moure et al., 2009; Sun et al., 2012) were conducted, aimed mainly to know the possible behavior of herbicides in soil.

Information about sorption of oxadiazon in soil contribute to better understand their behavior and fate in the environment, since the sorption affects mobility and degradation and hence the potential for contamination of surface and groundwater.

There is a lack of studies concerning the effects of soil chemical properties on the sorption of oxadiazon in tropical soils. Considering the above, the aim of this work was to evaluate the sorption capacity of oxadiazon and the effects of 17 chemical characteristics in 23 soils cultivated with Alliaceae.

\section{MATERIALS AND METHODS}

For the experiment, were collected 22 soil samples from the plow layer $(0.000 .20 \mathrm{~m})$, marked with Global Positioning System (GPS) 
in different areas cultivated with Alliaceae garlic and onion (Figure 1), with soils classified as dystrophic red latosol (oxisol), clayey texture, besides the washed sand substrate, considered as inert material.

The soil and sand washed were sieved through a $2.0 \mathrm{~mm}$ mesh. The process of washing sand previously incubated with diluted $\mathrm{HCl}$ solution in water at $6.0 \%$ for 24 hours, followed by new incubation with $\mathrm{NaOH}$ solution in the same proportion for 24 hours; and, as a result, it was washed with running water until reaching a $\mathrm{pH}$ near 7.0.

Subsequently, the sand and soil samples were air-dried, and $100 \mathrm{~g}$ of substrate were put in plastic pots with a capacity of $0.1 \mathrm{~L}$. Chemical analyzes of each soil sample were conducted (Table 1).

The experiment was conducted in a design with randomized blocks with four replications and the treatments consisted of the substrates and increasing rates of oxadiazon. The experimental unit consisted of a pot with two plants of the species bio-indicator (Avena sativa), sensitive to oxadiazon (Fourie, 1992).

A single application was conducted $(0.01 \mathrm{~L})$ of balanced nutrient solution at 10 days after emergence (DAE), containing $4 \%$ of $\mathrm{N}$, $14 \%$ of $\mathrm{P}_{2} \mathrm{O}_{5}$ and $8 \%$ of $\mathrm{K}_{2} \mathrm{O}$, with primary macronutrients and micronutrients (Green Root $1.25 \mathrm{~g} \mathrm{~L}^{-1}$ ), diluting $0.005 \mathrm{~L}$ of the solution in $1 \mathrm{~L}$ of water. At $21 \mathrm{DAE}$, the aerial part was collected and taken to forced ventilation oven at $72{ }^{\circ} \mathrm{C}$ for $48 \mathrm{~h}$.

The 10 oxadiazon increasing rates were applied in pre-emergence $(0.00 ; 0.49 ; 0.98$; $1.95 ; 3.91 ; 7.81 ; 15.63 ; 31.25 ; 62.50$; and $125.00 \mathrm{~g} \mathrm{ha}^{-1}$ ) under all the pots containing the soils substrates and 20 rates $(0.00 ; 0.06 ; 0.09$; $0.12 ; 0.18 ; 0.24 ; 0.37 ; 0.49 ; 0.73 ; 0.98 ; 1.46$; $1.95 ; 2.93 ; 3.91 ; 5.86 ; 7.81 ; 11.72 ; 15.63 ; 31.25$; and $62.50 \mathrm{~g} \mathrm{ha}^{-1}$ ) in the washed sand, to prepare

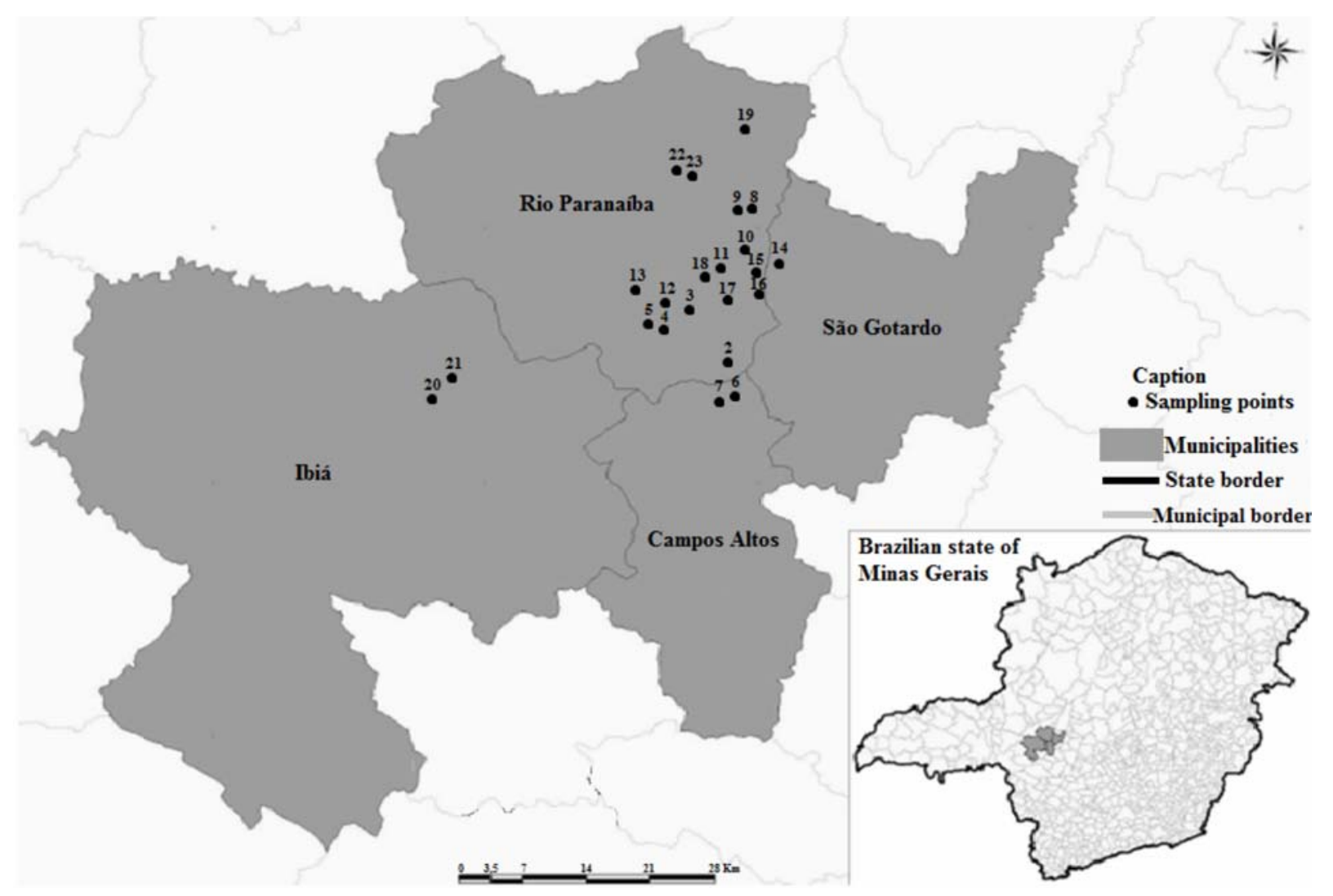

Figure 1 - Location of the sampling points in cultivated soils of the cerrado in the Brazilian state of Minas Gerais (except washed sand - sample 1), used in the bioassay of sorption of oxadiazon. Rio Paranaíba, MG, 2012. 
Table 1 - Substrate chemical characteristics of soils used in the experiment. Rio Paranaíba, MG, 2012

\begin{tabular}{|c|c|c|c|c|c|c|c|c|c|c|c|c|c|c|c|c|c|}
\hline \multirow{2}{*}{ Sample ${ }^{1 /}$} & \multicolumn{2}{|c|}{$\mathrm{pH}$} & $\mathrm{P}(\mathrm{res})$ & $\mathrm{P}$ (melh) & $\mathrm{P}(\mathrm{rem})$ & $\mathrm{K}$ & $\mathrm{Ca}^{2+}$ & $\mathrm{Mg}^{2+}$ & $\mathrm{Al}^{3+}$ & $\mathrm{H}+\mathrm{Al}$ & \multirow{2}{*}{\multicolumn{2}{|c|}{\begin{tabular}{c|c}
$\mathrm{OM}$ & $\mathrm{OC}$ \\
$\left(\mathrm{g} \mathrm{dm}^{-3}\right)$
\end{tabular}}} & \multirow{2}{*}{\multicolumn{3}{|c|}{\begin{tabular}{c|c|c} 
SB & $\mathrm{t}$ & $\mathrm{T}$ \\
\multicolumn{3}{c}{$\left(\mathrm{cmol}_{\mathrm{c}} \mathrm{dm}^{-3}\right)$}
\end{tabular}}} & \multirow{2}{*}{\multicolumn{2}{|c|}{\begin{tabular}{l|l}
$\mathrm{V}$ & $\mathrm{m}$ \\
& $(\%)$
\end{tabular}}} \\
\hline & $\left(\mathrm{H}_{2} \mathrm{O}\right)$ & $\left(\mathrm{CaCl}_{2}\right)$ & \multicolumn{3}{|c|}{$\mathrm{mg} \mathrm{dm}^{-3}(\mathrm{ppm})$} & \multicolumn{5}{|c|}{$\left(\mathrm{cmol}_{\mathrm{c}} \mathrm{dm}^{-3}\right)$} & & & & & & & \\
\hline 1 & 7.00 & 7.00 & 0.00 & 0.00 & 0.00 & 0.00 & 0.00 & 0.00 & 0.00 & 0.00 & 0.00 & 0.00 & 0.00 & 0.00 & 0.00 & 0.00 & 0.00 \\
\hline 2 & 5.30 & 4.20 & 12.00 & 7.00 & 10.50 & 0.33 & 1.50 & 1.20 & 0.15 & 4.08 & 52.00 & 30.20 & 3.03 & 3.18 & 7.11 & 42.60 & 4.70 \\
\hline 3 & 6.00 & 5.30 & 266.00 & 93.70 & 13.70 & 0.37 & 4.00 & 0.80 & 0.00 & 4.13 & 34.00 & 19.70 & 5.17 & 5.17 & 9.30 & 55.60 & 0.00 \\
\hline 4 & 6.20 & 5.30 & 320.00 & 96.10 & 14.70 & 0.30 & 4.30 & 1.00 & 0.00 & 2.13 & 33.00 & 19.10 & 5.60 & 5.60 & 7.73 & 72.40 & 0.00 \\
\hline 5 & 5.60 & 5.10 & 116.00 & 63.50 & 8.20 & 0.21 & 2.70 & 0.60 & 0.00 & 4.63 & 35.00 & 20.30 & 3.51 & 3.51 & 8.14 & 43.10 & 0.00 \\
\hline 6 & 6.20 & 5.50 & 294.00 & 96.50 & 17.60 & 0.37 & 4.80 & 1.10 & 0.00 & 2.20 & 38.00 & 22.00 & 6.27 & 6.27 & 8.47 & 74.00 & 0.00 \\
\hline 7 & 6.30 & 5.40 & 217.00 & 91.40 & 18.30 & 0.54 & 3.80 & 1.20 & 0.00 & 3.53 & 39.00 & 22.60 & 5.54 & 5.54 & 9.07 & 61.10 & 0.00 \\
\hline 8 & 6.00 & 5.30 & 219.00 & 89.60 & 18.50 & 0.26 & 3.20 & 1.20 & 0.00 & 4.13 & 34.00 & 19.70 & 4.66 & 4.66 & 8.79 & 53.00 & 0.00 \\
\hline 9 & 5.80 & 4.70 & 121.00 & 62.80 & 13.10 & 0.58 & 2.20 & 1.10 & 0.00 & 3.92 & 36.00 & 20.90 & 3.88 & 3.88 & 7.80 & 49.70 & 0.00 \\
\hline 10 & 6.50 & 5.80 & 160.00 & 68.20 & 10.90 & 0.41 & 4.40 & 1.00 & 0.00 & 2.68 & 35.00 & 20.30 & 5.81 & 5.81 & 8.49 & 68.40 & 0.00 \\
\hline 11 & 5.80 & 5.10 & 112.00 & 50.90 & 12.20 & 0.50 & 3.70 & 1.40 & 0.00 & 2.92 & 39.00 & 22.60 & 5.60 & 5.60 & 8.52 & 65.70 & 0.00 \\
\hline 12 & 6.90 & 6.10 & 290.00 & 90.30 & 9.50 & 0.14 & 4.90 & 1.70 & 0.00 & 2.13 & 37.00 & 21.50 & 6.74 & 6.74 & 8.87 & 76.00 & 0.00 \\
\hline 13 & 6.20 & 5.10 & 122.00 & 53.20 & 11.00 & 0.63 & 3.30 & 1.40 & 0.00 & 2.83 & 39.00 & 22.60 & 5.33 & 5.33 & 8.16 & 65.30 & 0.00 \\
\hline 14 & 6.40 & 5.70 & 167.00 & 49.10 & 8.40 & 0.41 & 3.70 & 1.10 & 0.00 & 3.04 & 35.00 & 20.30 & 5.21 & 5.21 & 8.25 & 63.20 & 0.00 \\
\hline 15 & 6.20 & 5.30 & 187.00 & 81.90 & 14.20 & 0.45 & 3.40 & 1.00 & 0.00 & 2.47 & 35.00 & 20.30 & 4.85 & 4.85 & 7.32 & 66.30 & 0.00 \\
\hline 16 & 6.30 & 5.60 & 233.00 & 96.50 & 15.70 & 0.34 & 3.80 & 1.10 & 0.00 & 3.45 & 37.00 & 21.50 & 5.24 & 5.24 & 8.69 & 60.30 & 0.00 \\
\hline 17 & 5.80 & 5.20 & 182.00 & 85.30 & 18.30 & 0.64 & 3.20 & 0.70 & 0.00 & 2.92 & 35.00 & 20.30 & 4.54 & 4.54 & 7.46 & 60.90 & 0.00 \\
\hline 18 & 6.50 & 5.80 & 296.00 & 95.70 & 17.90 & 0.46 & 4.40 & 1.30 & 0.00 & 2.86 & 35.00 & 20.30 & 6.16 & 6.16 & 9.02 & 68.30 & 0.00 \\
\hline 19 & 6.70 & 5.90 & 200.00 & 70.60 & 4.90 & 0.44 & 5.80 & 1.70 & 0.00 & 1.73 & 37.00 & 21.50 & 7.94 & 7.94 & 9.67 & 82.10 & 0.00 \\
\hline 20 & 6.10 & 5.40 & 150.00 & 60.00 & 13.10 & 0.78 & 3.80 & 1.10 & 0.00 & 3.04 & 31.00 & 18.00 & 5.68 & 5.68 & 8.72 & 65.10 & 0.00 \\
\hline 21 & 6.20 & 5.40 & 127.00 & 56.00 & 12.40 & 0.67 & 3.50 & 1.10 & 0.00 & 2.27 & 29.00 & 16.80 & 5.27 & 5.27 & 7.54 & 69.90 & 0.00 \\
\hline 22 & 6.00 & 5.70 & 98.00 & 50.20 & 12.80 & 0.32 & 5.00 & 1.40 & 0.00 & 1.80 & 43.00 & 24.90 & 6.72 & 6.72 & 8.52 & 78.90 & 0.00 \\
\hline 23 & 7.20 & 6.30 & 250.00 & 96.50 & 14.90 & 1.37 & 5.90 & 2.30 & 0.00 & 1.74 & 49.00 & 28.40 & 9.57 & 9.57 & 11.31 & 84.60 & 0.00 \\
\hline Average & 6.23 & 5.49 & 179.96 & 69.78 & 12.64 & 0.46 & 3.71 & 1.15 & 0.01 & 2.81 & 35.52 & 20.60 & 5.32 & 5.32 & 8.13 & 62.02 & 0.20 \\
\hline $\begin{array}{l}\text { Standard } \\
\text { deviation }\end{array}$ & 0.45 & 0.55 & 86.28 & 27.28 & 4.53 & 0.27 & 1.31 & 0.44 & 0.03 & 1.04 & 9.28 & 5.38 & 1.80 & 1.79 & 1.98 & 17.45 & 0.98 \\
\hline
\end{tabular}

Source: Fertilab - Laboratório de Análises de Solo e Foliar. São Gotardo, MG.

${ }^{1 /} \mathrm{P}($ res $)$ = resin phosphorus; $\mathrm{P}($ melh $)$ = Mehlich phosphorus; $\mathrm{P}(\mathrm{rem})$ = remaining phosphorus; OM = organic matter (calorimetric method); $\mathrm{OC}=$ organic carbon; $\mathrm{t}=$ effective cation exchange capacity; $\mathrm{T}=$ cation exchange capacity at $\mathrm{pH} 7.0$; $\mathrm{V}=$ saturation by bases; $\mathrm{m}=$ saturation by aluminum.

the standard curve of sorption (Firmino et al., 2008).

In the applications of oxadiazon a pressurized coast sprayer was used with $\mathrm{CO}_{2}$ at $200 \mathrm{kPa}$, equipped with a bar of $0.5 \mathrm{~m}$ composed of two flat spray tips ("range" type) 110.02 , with a volume of syrup equivalent to $200 \mathrm{~L} \mathrm{ha}^{-1}$. The application of oxadiazon was made with the humidity of the environment of $30 \%$, soil moisture of $42 \%$, atmospheric air temperature of $29{ }^{\circ} \mathrm{C}$ and wind speed of $3.5 \mathrm{~km} \mathrm{~h}^{-1}$.

For the interpretation of the results, the values were compared to the treatment with the herbicide (zero rate). The LD50 (lethal rate able to inhibit $50 \%$ of the dry matter accumulation of the bio-indicator) and the confidence interval of $95 \%$ were determined by Probit analysis (Goss et al., 2009). From the data obtained from LD50 on substrates of soil and sand, the RS equation was used = [(LD50soil - LD50sand)/LD50sand] (Souza et al., 1996), to express the relation of sorption (RS) of the soil compared to the response obtained in sand by means of bioassay as an indirect method for quantitation of waste (Szmigielska et al., 1998). It is considered that the higher values of RS indicate higher sorption capacity of the herbicide studied into the soil and, therefore, a lower potential for leaching of the herbicide into the soil profile.

Pearson correlation analysis was performed among the chemical characteristics of the soils assessed, and the LD50 of the oxadiazon by the $t$ test $(p<0.01$ and 0.05$)$. 
Linear regression analysis was also performed among the LD50 values of the oxadiazon and the organic matter content in the soil (except washed sand), by the $F$ test $(p<0.01)$. Path analysis, which unfolds the correlations estimated in direct and indirect effects of characters on one basic variable (LD50) was quantified only for the significant correlations. All statistical analysis were performed in the Genes program (Cruz, 2006).

\section{RESULTS AND DISCUSSION}

In the washed sand substrate (sample 1), the rate of $9.74 \mathrm{~g} \mathrm{ha}^{-1}$ of the oxadiazon (available in the soil) was sufficient to reduce $50 \%$ of the dry mass of the aerial part of the oats bio-indicator (Avena sativa) (Table 2). This result confirms the high sensitivity of oats to oxadiazon, evidencing the use as bio-indicator for this herbicide.

Table 2 - Lethal rate able to inhibit $50 \%$ of the dry mass accumulation of the aerial part of the bio-indicator (LD50), confidence interval at 95\%, and the sorption relation (RS) for substrates of washed sand and cultivated soils of the cerrado in Minas Gerais. Rio Paranaíba, MG, 2012

\begin{tabular}{|c|c|c|c|c|}
\hline \multirow[t]{2}{*}{ Sample ${ }^{1 /}$} & \multirow{2}{*}{$\begin{array}{l}\text { LD50 } \\
\left(\mathrm{g} \mathrm{ha}^{-1}\right)\end{array}$} & \multicolumn{2}{|c|}{$\begin{array}{c}\text { Confidence interval at } \\
95 \%\end{array}$} & \multirow[t]{2}{*}{$\mathrm{RS}$} \\
\hline & & Minimum & Maximum & \\
\hline 1 & 9.7411 & 8.4869 & 11.2437 & - \\
\hline 2 & 528.0912 & 492.3435 & 578.1634 & 53.2127 \\
\hline 3 & 154.1518 & 132.8271 & 180.9461 & 14.8249 \\
\hline 4 & 127.1026 & 105.6993 & 153.7940 & 12.0481 \\
\hline 5 & 309.1174 & 260.2181 & 380.5146 & 30.7333 \\
\hline 6 & 139.6343 & 109.2719 & 184.9395 & 13.3346 \\
\hline 7 & 306.2613 & 207.5654 & 550.3201 & 30.4401 \\
\hline 8 & 93.9248 & 74.4852 & 118.9231 & 8.6421 \\
\hline 9 & 133.5501 & 111.9682 & 161.5546 & 12.7100 \\
\hline 10 & 83.2561 & 68.7964 & 100.1738 & 7.5469 \\
\hline 11 & 188.3500 & 135.7106 & 290.9707 & 18.3356 \\
\hline 12 & 138.9968 & 112.6058 & 175.8252 & 13.2691 \\
\hline 13 & 416.9082 & 326.2873 & 568.7160 & 41.7989 \\
\hline 14 & 69.3272 & 50.8447 & 96.4899 & 6.1170 \\
\hline 15 & 19.5972 & 1.5660 & 44.3907 & 1.0118 \\
\hline 16 & 88.3191 & 61.8567 & 126.0854 & 8.0666 \\
\hline 17 & 109.4462 & 83.8019 & 147.2100 & 10.2355 \\
\hline 18 & 246.9210 & 187.7159 & 352.8427 & 24.3484 \\
\hline 19 & 138.5987 & 111.7322 & 176.4142 & 13.2282 \\
\hline 20 & 94.1549 & 78.2459 & 113.5733 & 8.6657 \\
\hline 21 & 110.4422 & 95.6372 & 127.1088 & 10.3378 \\
\hline 22 & 280.1504 & 178.5379 & 298.2964 & 27.7596 \\
\hline 23 & 321.2256 & 298.3574 & 353.7457 & 31.9763 \\
\hline
\end{tabular}

1/ Substrate of washed sand and samples of soil cultivated of the cerrado in Minas Gerais.
The LD50 - lethal rate of the oxadiazon (528.09 $\mathrm{g} \mathrm{ha}^{-1}$ ) able to inhibit $50 \%$ of the dry mass of the aerial part of the bio-indicator was more significant for the Cerrado soil substrate (sample 2), with confidence minimum and maximum interval at $95 \%$ of 492.34 and $578.16 \mathrm{~g} \mathrm{ha}^{-1}$, respectively, resulting in greater relative sorption - RS (53.2) compared with the other soils (Table 2). This fact is explained by this being a soil sample, among those studied, with higher organic matter content $\left(52.00 \mathrm{~g} \mathrm{dm}^{-3}\right)$ (Table 2). According to Freitas et al. (1998), the LD50 of diuron (100 a $900 \mathrm{~g} \mathrm{ha}^{-1}$ ) is also dependent on the organic matter content in the soil, where the addition of $0,20,40$ and $60 \mathrm{~m}^{3} \mathrm{ha}^{-1}$ of pig slurry provided RS of 23.38, 25.32, 28.70, and 30.55 respectively; in the addition of $0,30,60$ and $90 \mathrm{t} \mathrm{ha}^{-1}$ of organic compost produced from bagasse of sugarcane, the RS were 28.76, $32.75,34.59$, and 39.94 respectively.

In China, the sorption of ethametsulfuronmethyl ranged from 68.4 to $92.4 \%$ in soils without the addition of $\mathrm{OM}$ - organic matter (1.02\% of OC - organic carbon) and adding (2.61\% of OC), which was attributed to the high sorption capacity of the insoluble OM added to the soil in the presence of the herbicide (Si et al., 2006).

The weed control is also declining, especially in the presence of higher concentrations of OM in the soil, indicating less amount of the bioavailable herbicide in the soil solution. However, sample 21 of soil substrate had the lowest OM content $\left(29.00 \mathrm{~g} \mathrm{dm}^{-3}\right)$ in relation to other substrates and was not directly proportional to the RS.The lower RS (1.01) is represented in sample 15 with $35.00 \mathrm{~g} \mathrm{dm}^{-3}$ of OM (Table 2). Thus, not only the level of OM in the soil influences the sorption potential of the oxadiazon, but due to other soil chemical characteristics, which should be studied.

The relationship between the OM content in the soil and the LD50 of the oxadiazon in the soils studied was linear; the addition of $1.00 \%$ of $\mathrm{OM}$, corresponding to $10.00 \mathrm{~g} \mathrm{dm}^{-3}$, provides a LD50 of approximately $179.52 \mathrm{~g} \mathrm{ha}^{-1}$ (Figure 2). As already reported by Hoque et al. (2007), the oxadiazon sorption by the soil is a rapid process and linearly related to the concentration, depending on the $\mathrm{OC}$ content and occurs within two hours. 


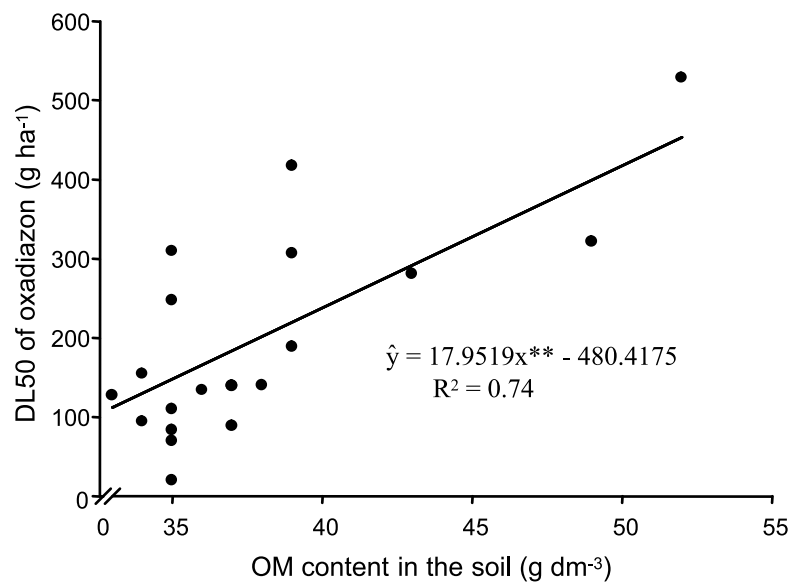

** $\mathrm{p}<0.01$ by the $\mathrm{F}$ test.

Figure 2 - Relationship between the OM content in the soil and the LD50 of oxadiazon for substrates of cultivated soils of the cerrado in Minas Gerais (except washed sand sample 1). Rio Paranaíba, MG, 2012.

The correlations of LD50 of oxadiazon with the chemical characteristics of the soils confirm the influence of the soil variability in the sorption processes of the herbicide (Table 3). The positive correlations, 0.63 $(p<0.01)$, of the OM and OC contents of the soil with the LD50 of the oxadiazon demonstrate the higher sorption capacity of the herbicide in soil with high levels of OM and OC. This behavior is extremely important from a practical point of view, because the efficiency of the oxadiazon in weed control can be reduced in soils rich in OM, because of the unavailability and/or degradation of the herbicide (Prata \& Lavorenti, 2000).

The OM is the universal colloid of the soil, retaining most of the herbicides (Moure et al., 2009), with highly heterogeneous structures (Cornelissen et al., 2005; Chefetz \& Xing, 2009). Due to its high specific surface area and the diversity of functional groups, the $\mathrm{OM}$ can interact with the organic molecules of different shapes. The possible mechanisms involved in the interaction among herbicides of low water solubility, such as oxadiazon (Garbi et al., 2006), with $0.57 \mathrm{mg} \mathrm{L}^{-1}$ (Footprint, 2013), and the OM are hydrogen bonding, Van der Waals forces, hydrophobic interactions and charge transfer, and they can operate concurrently in the sorption of the same molecule (Sheng et al., 2001). The molecular

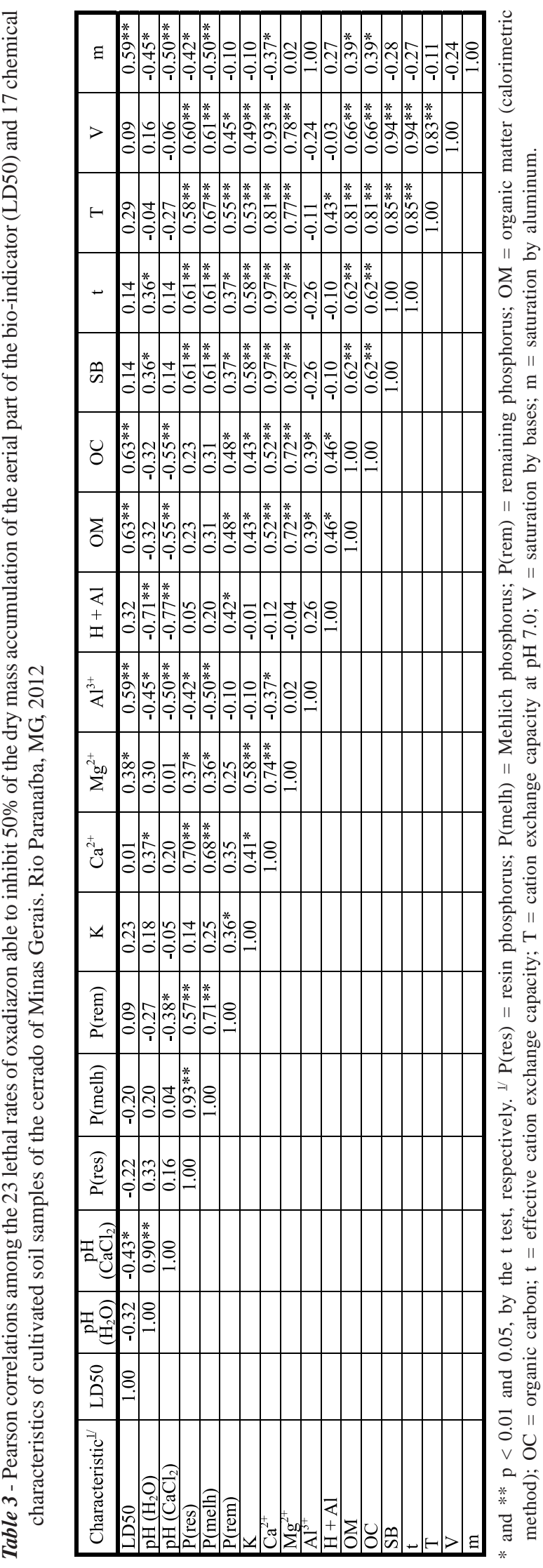

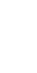

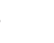


nature of the OM of the soil has been shown to be the key to determine the sorption of nonionic herbicides (Correia \& Langenbach, 2006). The molecular OM and its complex structure influence the behavior of fluridone and norflurazon, providing greater sorption (Sun et al., 2012). In China, the amount of sorption of butachlor in soils (1.50 a 4.78\% de OM) was positively correlated with the OM content of the soil (Xu et al., 2005).

Oxadiazon sorption is related to the OC content of the soils (Comoretto et al., 2008). In addition, the sorption of the herbicide in the suspended sediments can reduce the degradation rates of oxadiazon in the soil (Lin et al., 2000; Ying \& Williams, 2000), forming carboxylic acid, phenolic derivatives and polar dealkylated products, which were identified as the metabolites of degradation of oxadiazon in the soil (Ying \& Williams, 1999).

The sorption in the soil of s-triazines atrazine, terbuthylazine and simazine was mainly related to the OC content, hydrophobicity and aromaticity of humic acid, implying a predominant role of weak links and dispersive forces (Celano et al., 2008). Studies developed by Martinazzo et al. (2011) also showed that atrazine sorption was enhanced by the functionalization of the aliphatic structures, such as non-polar sites in the composition of the OM of Latosols (9.5 to $38.3 \mathrm{~g} \mathrm{~kg}^{-1}$ of OC).

Usually, the sorption coefficient is calculated in the retention studies of herbicides, considering the interactions herbicide-soil, not only as a surface phenomenon, but as a phenomenon that occurs evenly on the entire volume of the soil $\left(\mathrm{K}_{\mathrm{d}}\right)$ or of the organic matter $\left(\mathrm{K}_{\mathrm{oc}}\right)$ (Gomes et al., 2002). Given the above, Ying $\&$ Williams (2000) reported that oxadiazon is highly sorbed in the soil, with high $\mathrm{K}_{\mathrm{d}}$, varying from 23.43 to $28.07 \mathrm{~mL} \mathrm{~g}^{-1}$, and $\mathrm{K}_{\mathrm{oc}}$ of 2.343 to $2.718 \mathrm{~mL} \mathrm{~g}^{-1}$, in soils with $\mathrm{pH} 7.2,45.5 \%$ of clay and $1.00 \%$ of $\mathrm{OC}$ and with $\mathrm{pH} 4.7,3.0 \%$ of clay and $0.86 \%$ of $\mathrm{OC}$, respectively; from these results, the authors claim that the sorption of oxadiazon is clearly not related to the clay content of the soil, but with the OC content. The highest values of this coefficient are indicative of better retention of the herbicide by the soil and, consequently, less leaching (Oliveira et al., 2004).

Positive correlation $(0.59 ; \mathrm{p}<0.01)$ was also noticed for the aluminum saturation $(\mathrm{m})$ with the LD50 of the oxadiazon, highlighting sample 2, with high levels of OM $\left(52 \mathrm{~g} \mathrm{dm}^{-3}\right)$ and $\mathrm{m}(4.7 \%)$. The $\mathrm{m}$ refers to the percentage of negative charges of the soil that is occupied by the chargeable $\mathrm{Al}^{3+}$, next do the $\mathrm{pH} 7.0$ of the soil. As a result, the correlation with levels of $\mathrm{Al}^{3+}$ corroborate the result (Table 3), which are related to the higher retention capacity of oxadiazon, nonionic herbicide, in soils with high toxicity for aluminum. The data confront the ones from Albuquerque et al. (2001), where the oxides of $\mathrm{Fe}$ and $\mathrm{Al}$ in Purple Latosolic had no capacity to absorb atrazine, derived from a weak base.

For $\mathrm{Mg}^{2+}$ content in the soils and oxadiazon sorption, the correlation was relatively low, but positive $(0.38 ; \mathrm{p}<0.05)$, showing the highest sorption capacity of the herbicide in soils rich in $\mathrm{Mg}^{2+}$ (Table 3). The effect of reduction in the availability of flumioxazin, according to Lima et al. (1999), may be related to phenomena of interaction among the cations of the soil sorption complex and the electron rich centers of the herbicide molecule, where sorption may have occurred among the herbicide molecules and binding cations (calcium and/ or magnesium) of the exchange complex and the clays and/or OM of the soil.

Low negative correlation $(-0.43 ; p<0.05)$ was found between the sorption relation of the oxadiazon and the $\mathrm{pH}\left(\mathrm{CaCl}_{2}\right)$ of the soils studied (Table 3). These results demonstrated that for the soils studied the values of $\mathrm{pH}\left(\mathrm{CaCl}_{2}\right)$ are inversely related with the oxadiazon sorption by the substrate. As for works developed by Araújo et al. (2012), even regarding diuron, nonionic herbicide, using only clay fraction minerals resulted in greater sorption capacity for the herbicide for oxides of $\mathrm{Fe}$ in $\mathrm{pH} 7.0$ (constant of Freundlich $\mathrm{Kf}=1.47$ ), followed by smectite in $\mathrm{pH} 7.0$ and oxides of $\mathrm{Fe}$ in $\mathrm{pH} 3.5$.

The data are consistent with those of Oliveira et al. (2005), who reported lower flazasulfuron sorption in soils with higher $\mathrm{pH}$ values, indicating a higher risk of leaching. The imazaquin sorption is higher in samples 
with lower $\mathrm{pH}$ values and higher levels of OM; therefore, the effect of the OM on retention of imazaquin is $\mathrm{pH}$ dependent (Oliveira et al., 2004). Conditions of soils with low $\mathrm{pH}$ values tend to increase the interaction between molecules of the herbicide and the colloids in the soil, especially by the OC (Berglof et al., 2003).

Table 4 - Estimates of direct and indirect effects of 23 rates of oxadiazon able to inhibit 50\% of the dry mass accumulation of the aerial part of the bio-indicator (LD50) on 17 chemical characteristics of cultivated soils of the cerrado in Minas Gerais, obtained by the method of path analysis. Rio Paranaíba, MG, 2012

\begin{tabular}{|c|c|c|c|c|c|c|c|c|c|c|c|}
\hline Characteristic & & & Estimate & Characteristic & & & Estimate & Characteristic & & & Estimate \\
\hline LD50 & \begin{tabular}{|l|}
$\mathrm{ED}^{(1)}$ \\
over
\end{tabular} & $\begin{array}{l}\mathrm{pH} \\
\left(\mathrm{CaCl}_{2}\right)\end{array}$ & -0.13765023 & LD50 & $\begin{array}{l}\text { ED } \\
\text { over }\end{array}$ & $\mathrm{Mg}^{2+}$ & 0.18053865 & LD50 & $\begin{array}{l}\text { ED } \\
\text { over }\end{array}$ & $\mathrm{Al}^{3+}$ & -0.11388043 \\
\hline $\mathrm{pH}\left(\mathrm{CaCl}_{2}\right)$ & $\mathrm{EI}^{(2)}$ & \begin{tabular}{|l}
$\mathrm{pH}$ \\
$\left(\mathrm{H}_{2} \mathrm{O}\right)$ \\
\end{tabular} & -0.17086834 & $\mathrm{Mg}^{2+}$ & EI via & $\begin{array}{l}\mathrm{pH} \\
\left(\mathrm{H}_{2} \mathrm{O}\right)\end{array}$ & -0.05695611 & $\mathrm{Al}^{3+}$ & EI via & $\begin{array}{l}\mathrm{pH} \\
\left(\mathrm{H}_{2} \mathrm{O}\right)\end{array}$ & 0.08543417 \\
\hline $\mathrm{pH}\left(\mathrm{CaCl}_{2}\right)$ & EI via & $\mathrm{P}(\mathrm{res})$ & 0.07634655 & $\mathrm{Mg}^{2+}$ & EI via & $\begin{array}{l}\mathrm{pH} \\
\left(\mathrm{CaCl}_{2}\right) \\
\end{array}$ & -0.00137650 & $\mathrm{Al}^{3+}$ & EI via & \begin{tabular}{|l|}
$\mathrm{pH}$ \\
$\left(\mathrm{CaCl}_{2}\right)$ \\
\end{tabular} & 0.06882512 \\
\hline $\mathrm{pH}\left(\mathrm{CaCl}_{2}\right)$ & EI via & $\mathrm{P}($ melh) & -0.02296625 & $\mathrm{Mg}^{2+}$ & EI via & $\mathrm{P}(\mathrm{res})$ & 0.17655141 & $\mathrm{Al}^{3+}$ & EI via & $\mathrm{P}(\mathrm{res})$ & -0.20040970 \\
\hline $\mathrm{pH}\left(\mathrm{CaCl}_{2}\right)$ & EI via & $\mathrm{P}(\mathrm{rem})$ & 0.01707314 & $\mathrm{Mg}^{2+}$ & EI via & $\mathrm{P}(\mathrm{melh})$ & -0.20669626 & $\mathrm{Al}^{3+}$ & EI via & $\mathrm{P}$ (melh) & 0.28707814 \\
\hline $\mathrm{pH}\left(\mathrm{CaCl}_{2}\right)$ & EI via & $\mathrm{K}$ & -0.00788480 & $\mathrm{Mg}^{2+}$ & EI via & $\mathrm{P}(\mathrm{rem})$ & -0.01123233 & $\mathrm{Al}^{3+}$ & EI via & P(rem) & 0.00449293 \\
\hline $\mathrm{pH}\left(\mathrm{CaCl}_{2}\right)$ & EI via & $\mathrm{Ca}^{2+}$ & 0.09167453 & $\mathrm{Mg}^{2+}$ & EI via & $\mathrm{K}$ & 0.09146373 & $\mathrm{Al}^{3+}$ & EI via & $\mathrm{K}$ & -0.01576961 \\
\hline $\mathrm{pH}\left(\mathrm{CaCl}_{2}\right)$ & EI via & $\mathrm{Mg}^{2+}$ & 0.00180539 & $\mathrm{Mg}^{2+}$ & EI via & $\mathrm{Ca}^{2+}$ & 0.33919577 & $\mathrm{Al}^{3+}$ & EI via & $\mathrm{Ca}^{2+}$ & -0.16959789 \\
\hline $\mathrm{pH}\left(\mathrm{CaCl}_{2}\right)$ & EI via & $\mathrm{Al}^{3+}$ & 0.05694022 & $\mathrm{Mg}^{2+}$ & EI via & $\mathrm{Al}^{3+}$ & -0.00227761 & $\mathrm{Al}^{3+}$ & EI via & $\mathrm{Mg}^{2+}$ & 0.00361077 \\
\hline $\mathrm{pH}\left(\mathrm{CaCl}_{2}\right)$ & EI via & $\mathrm{H}+\mathrm{Al}$ & -0.42134791 & $\mathrm{Mg}^{2+}$ & EI via & $\mathrm{H}+\mathrm{Al}$ & -0.02188820 & $\mathrm{Al}^{3+}$ & EI via & $\mathrm{H}+\mathrm{Al}$ & 0.14227332 \\
\hline $\mathrm{pH}\left(\mathrm{CaCl}_{2}\right)$ & EI via & $\mathrm{OM}$ & -1.17207580 & $\mathrm{Mg}^{2+}$ & EI via & OM & 1.53435377 & $\mathrm{Al}^{3+}$ & EI via & $\mathrm{OM}$ & 0.83110829 \\
\hline $\mathrm{pH}\left(\mathrm{CaCl}_{2}\right)$ & EI via & $\mathrm{OC}$ & 0.34650000 & $\mathrm{Mg}^{2+}$ & EI via & $\mathrm{OC}$ & -0.45360000 & $\mathrm{Al}^{3+}$ & EI via & $\mathrm{OC}$ & -0.24570000 \\
\hline $\mathrm{pH}\left(\mathrm{CaCl}_{2}\right)$ & EI via & SB & -0.14324934 & $\mathrm{Mg}^{2+}$ & EI via & SB & -0.89019230 & $\mathrm{Al}^{3+}$ & EI via & SB & 0.26603448 \\
\hline $\mathrm{pH}\left(\mathrm{CaCl}_{2}\right)$ & EI via & $\mathrm{t}$ & 0.36252053 & $\mathrm{Mg}^{2+}$ & EI via & $\mathrm{t}$ & 2.25280612 & $\mathrm{Al}^{3+}$ & EI via & $t$ & -0.67325240 \\
\hline $\mathrm{pH}\left(\mathrm{CaCl}_{2}\right)$ & EI via & $\mathrm{T}$ & 0.49038612 & $\mathrm{Mg}^{2+}$ & EI via & $\mathrm{T}$ & -1.39850857 & $\mathrm{Al}^{3+}$ & EI via & $\mathrm{T}$ & 0.19978694 \\
\hline $\mathrm{pH}\left(\mathrm{CaCl}_{2}\right)$ & EI via & $\mathrm{V}$ & 0.08827416 & $\mathrm{Mg}^{2+}$ & EI via & $\mathrm{V}$ & -1.14756411 & $\mathrm{Al}^{3+}$ & EI via & $\mathrm{V}$ & 0.35309665 \\
\hline $\mathrm{pH}\left(\mathrm{CaCl}_{2}\right)$ & EI via & $\mathrm{m}$ & 0.11717411 & $\mathrm{Mg}^{2+}$ & EI via & $\mathrm{m}$ & -0.00468696 & $\mathrm{Al}^{3+}$ & EI via & $\mathrm{m}$ & -0.23434822 \\
\hline Total & & & -0.42734792 & Total & & & 0.37993050 & Total & & & 0.58878256 \\
\hline Characteristic & & & Estimate & Characteristic & & & Estimate & Characteristic & & & Estimate \\
\hline LD50 & \begin{tabular}{|l|} 
ED \\
over
\end{tabular} & $\mathrm{OM}$ & 2.13104690 & LD50 & \begin{tabular}{|l} 
ED \\
over \\
\end{tabular} & $\mathrm{OC}$ & -0.63000000 & DLD50 & $\begin{array}{l}\text { ED } \\
\text { over }\end{array}$ & $\mathrm{m}$ & -0.23434822 \\
\hline $\mathrm{OM}$ & EI via & $\begin{array}{l}\mathrm{pH} \\
\left(\mathrm{H}_{2} \mathrm{O}\right) \\
\end{array}$ & 0.06075319 & $\mathrm{OC}$ & EI via & \begin{tabular}{|l}
$\mathrm{pH}$ \\
$\left(\mathrm{H}_{2} \mathrm{O}\right)$ \\
\end{tabular} & 0.06075319 & $\mathrm{~m}$ & EI via & \begin{tabular}{|l}
$\mathrm{pH}$ \\
$\left(\mathrm{H}_{2} \mathrm{O}\right)$ \\
\end{tabular} & 0.08543417 \\
\hline $\mathrm{OM}$ & EI via & \begin{tabular}{ll|}
$\mathrm{pH}$ \\
$\left(\mathrm{CaCl}_{2}\right)$ \\
\end{tabular} & 0.07570763 & $\mathrm{OC}$ & EI via & $\begin{array}{l}\mathrm{pH} \\
\left(\mathrm{CaCl}_{2}\right)\end{array}$ & 0.07570763 & $\mathrm{~m}$ & EI via & $\begin{array}{l}\mathrm{pH} \\
\left(\mathrm{CaCl}_{2}\right)\end{array}$ & 0.06882512 \\
\hline $\mathrm{OM}$ & EI via & $\mathrm{P}($ res $)$ & 0.10974817 & $\mathrm{OC}$ & EI via & $\mathrm{P}(\mathrm{res})$ & 0.10974817 & $\mathrm{~m}$ & EI via & $\mathrm{P}(\mathrm{res})$ & -0.20040970 \\
\hline $\mathrm{OM}$ & EI via & $\mathrm{P}(\mathrm{melh})$ & -0.17798845 & $\mathrm{OC}$ & EI via & $\mathrm{P}(\mathrm{melh})$ & -0.17798845 & $\mathrm{~m}$ & EI via & $\mathrm{P}($ melh) & 0.28707814 \\
\hline $\mathrm{OM}$ & EI via & $\mathrm{P}(\mathrm{rem})$ & -0.02156607 & $\mathrm{OC}$ & EI via & $\mathrm{P}(\mathrm{rem})$ & -0.02156607 & $\mathrm{~m}$ & EI via & $\mathrm{P}(\mathrm{rem})$ & 0.00449293 \\
\hline $\mathrm{OM}$ & EI via & $\mathrm{K}$ & 0.06780931 & $\mathrm{OC}$ & EI via & $\mathrm{K}$ & 0.06780931 & $\mathrm{~m}$ & EI via & $\mathrm{K}$ & -0.01576961 \\
\hline $\mathrm{OM}$ & EI via & $\mathrm{Ca}^{2+}$ & 0.23835379 & $\mathrm{OC}$ & EI via & $\mathrm{Ca}^{2+}$ & 0.23835379 & $\mathrm{~m}$ & EI via & $\mathrm{Ca}^{2+}$ & -0.16959789 \\
\hline $\mathrm{OM}$ & EI via & $\mathrm{Mg}^{2+}$ & 0.12998783 & $\mathrm{OC}$ & EI via & $\mathrm{Mg}^{2+}$ & 0.12998783 & $\mathrm{~m}$ & \begin{tabular}{|l|} 
EI via \\
\end{tabular} & $\mathrm{Mg}^{2+}$ & 0.00361077 \\
\hline $\mathrm{OM}$ & EI via & $\mathrm{Al}^{3+}$ & -0.04441337 & $\mathrm{OC}$ & EI via & $\mathrm{Al}^{3+}$ & -0.04441337 & $\mathrm{~m}$ & \begin{tabular}{|l|} 
EI via \\
\end{tabular} & $\mathrm{Al}^{3+}$ & -0.11388043 \\
\hline $\mathrm{OM}$ & EI via & $\mathrm{H}+\mathrm{Al}$ & 0.25171434 & $\mathrm{OC}$ & EI via & $\mathrm{H}+\mathrm{Al}$ & 0.25171434 & $\mathrm{~m}$ & \begin{tabular}{|l|} 
EI via \\
\end{tabular} & $\mathrm{H}+\mathrm{Al}$ & 0.14774537 \\
\hline $\mathrm{OM}$ & EI via & OC & -0.63000000 & $\mathrm{OC}$ & EI via & OM & 2.13104690 & $\mathrm{~m}$ & \begin{tabular}{|l|} 
EI via \\
\end{tabular} & $\mathrm{OM}$ & 0.83110829 \\
\hline $\mathrm{OM}$ & EI via & SB & -0.63438992 & $\mathrm{OC}$ & EI via & SB & -0.63438992 & $\mathrm{~m}$ & \begin{tabular}{|l|} 
EI via \\
\end{tabular} & $\mathrm{OC}$ & -0.24570000 \\
\hline $\mathrm{OM}$ & EI via & $\mathrm{t}$ & 1.60544804 & $\mathrm{OC}$ & EI via & $\mathrm{t}$ & 1.60544804 & $\mathrm{~m}$ & \begin{tabular}{|l|} 
EI via \\
\end{tabular} & SB & 0.28649867 \\
\hline $\mathrm{OM}$ & EI via & $\mathrm{T}$ & -1.47115837 & $\mathrm{OC}$ & EI via & $\mathrm{T}$ & -1.47115837 & $\mathrm{~m}$ & \begin{tabular}{|l|} 
EI via \\
\end{tabular} & $\mathrm{t}$ & -0.69914673 \\
\hline $\mathrm{OM}$ & \begin{tabular}{|l|} 
EI via \\
\end{tabular} & $\mathrm{V}$ & -0.97101579 & $\mathrm{OC}$ & EI via & $\mathrm{V}$ & -0.97101579 & $\mathrm{~m}$ & \begin{tabular}{|l|} 
EI via \\
\end{tabular} & $\mathrm{T}$ & 0.19978694 \\
\hline OM & EI via & $\mathrm{m}$ & -0.09139581 & $\mathrm{OC}$ & EI via & $\mathrm{m}$ & -0.09139581 & $\mathrm{~m}$ & EI via & $\mathrm{V}$ & 0.35309665 \\
\hline Total & & & 0.62864142 & Total & & & 0.62864142 & Total & & & 0.58882447 \\
\hline \multicolumn{4}{|c|}{ Coefficient of determination $\left(\mathrm{r}^{2}\right)$} & 0.71067160 & & & & & & & \\
\hline \multicolumn{4}{|c|}{ Effect of the residual variable (EVR) } & 0.53789255 & & & & & & & \\
\hline
\end{tabular}

1/ Direct effect. 르 Indirect effect. 
The unfolding of the significant correlations of the chemical characteristics of the soils in their direct and indirect effects was conducted to assess the degree of importance of each explanatory variable with the LD50 of oxadiazon in the different soils evaluated (Table 4). The coefficient of determination $\left(\mathrm{r}^{2}\right)$ of the path analysis was 0.71 , and the effect of the residual variable was 0.53 (Table 4), indicating a good adjustment of the model to explain the sorption effect related to the variable under consideration.

It was found that the direct effect of the LD50 on the OM was high, being representative in greater proportion by the indirect effect of the effective cation exchange capacity (t) present in the the soils, as measured by the amount of cations that the soil can absorb to its $\mathrm{pH}$ (Table 4), especially, according to Ciotta et al. (2003), the increase in the values of $t$ with the accumulation of $\mathrm{OM}$ in the soil surface. However, the direct effect on the OC was negatively unrepresentative, highlighting the high magnitude of the indirect effect of the OM, because the $\mathrm{OC}$ is a major component of the $\mathrm{OM}$ of the soil and its stock is influenced by the management system adopted (Steiner et al., 2011), where it is assumed that the OM of the soil contains $58 \%$ of OC (Segnini et al., 2008).

It is noteworthy that the OC content of the soil is determined by the balance of the inputs, such as the incorporation of plant residues and the application of organic compounds, and the exits through the oxidation and decomposition of the OM of the soil (Leite et al., 2003).

The LD50 of the oxadiazon applied in pre-emergence in the soils has a direct effect in small magnitude and negative on the aluminum saturation $(\mathrm{m})$ and the content of exchangeable $\mathrm{Al}^{3+}$, being opposite to the sum of the direct and indirect effects (Table 4). The most representative features in this variable in the indirect effects are the content of $\mathrm{OM}$ and saturation by bases (V). Therefore, the indirect effects observed were responsible for the average correlation between the LD50 with the $\mathrm{m}$ and the content of $\mathrm{Al}^{3+}$.

The direct effect on the content of $\mathrm{Mg}^{2+}$ was unremarkable, with representative indirect effects via OM and $\mathrm{m}$ (Table 4). The direct effect of the LD50 on the $\mathrm{pH}\left(\mathrm{CaCl}_{2}\right)$ was low, being expressive its indirect effect via $\mathrm{OH}$ and content of $\mathrm{H}+\mathrm{Al}$ (potential acidity), present in the colloids of the soil (Table 4). This also explains why only the Pearson correlation study would not be efficient in selecting chemical characteristics of the soil during the sorption process of oxadiazon, reinforcing the most detailed study of the relations obtained by path analysis.

The apparent discrepancy is due to the analytical approach; however, while the simple correlation identifies the mutual associations among the characteristics, the path analysis allows the determination of the relative magnitude of each effect (Cruz et al., 2011).

Thus, more attention should be given to monitoring of oxadiazon in soils cultivated with Alliaceae in the Brazilian Cerrado, in which these agricultural soils have high organic matter content, which predisposes them to greater sorption and possibility of increasing the residual effect of this herbicide, causing phytotoxicity on successor crops.

The sorption of the oxadiazon is influenced by the chemical characteristics of the soils cultivated of the Brazilian Cerrado, highlighting the hydrogen potential $\mathrm{pH}$ in $\mathrm{CaCl}_{2}$ ), magnesium and aluminum content, organic matter, organic carbon and aluminum saturation. Thus, it is necessary to know the chemical characteristics of the soil in order to obtain an efficient control of weeds and also to minimize the risk of environmental contamination with applications of oxadiazon.

\section{ACKNOWLEDGEMENTS}

The CNPq (Conselho Nacional de Desenvolvimento Científico e Tecnológico) and the Fundação de Amparo a Pesquisa do Estado de Minas Gerais (FAPEMIG) for financial support.

\section{LITERATURE CITED}

AHANGAR, A. G. et al. Separating the effects of organic matter-mineral interactions and organic matter chemistry on the sorption of diuron and phenanthrene. Chemosphere, v. 72, n. 6, p. 886-890, 2008.

ALBARRÁN, A. et al. Effects of solid-olive mill waste addition to soil on sorption, degradation and leaching of the herbicide simazine. Soil Use Manag., v. 19, n. 2, p. 150-156, 2003. 
ALBUQUERQUE, M. A. et al. Mineralização e sorção de atrazina em latossolo roxo sob cultivo convencional e plantio direto. R. Bras. Ci. Solo, v. 25, n. 1, p. 179-188, 2001.

ARAUJO, I. C. L. et al. Sorção de diuron em minerais da fração argila. Química Nova, v. 35, n. 7, p. 1312-1317, 2012.

BEN-HUR, M. et al. Soluble and solid organic matter effects on atrazine adsorption in cultivated soils. Soil Sci. Soc. Am. J., v. 67, n. 4, p. 1140-1146, 2003.

BERGLOF, T. et al. Metsulfuron methyl sorption desorption in field-moist soils. J. Agric. Food Chem., v. 51, n. 12, p. 3598-3603, 2003.

BURNS, I. G.; HAYES, M. H. B.; STACEY, M. Studies of the adsorption of paraquat on soluble humic fractions by gel filtration and ultrafiltration techniques. Pestic. Sci., v. 4, n. 5, p. 629-641, 2006.

CABRERA, A. et al. Availability of triazine herbicides in aged soils amended with olive oil mill waste. J. Agric.

Food Chem., v. 56, n. 11, p. 4112-4119, 2008.

CELANO, G. et al. Interactions of three s-triazines with humic acids of different structure. J. Agric. Food Chem., v. 56, n. 16, p. 7360-7366, 2008.

CELIS, R.; BARRIUSO, E.; HOUOT, S. Sorption and desorption of atrazine by sludge-amended soil: dissolved organic matter effects. J. Environ. Quality, v. 27, n. 6, p. 1348-1356, 1998.

CHEFETZ, B.; XING, B. Relative role of aliphatic and aromatic moieties as sorption domains for organic compounds: a review. Environ. Sci. Technol., v. 43, n. 6, p. 1680-1688, 2009.

CIOTTA, M. N. et al. Matéria orgânica e aumento da capacidade de troca de cátions em solo com argila de atividade baixa sob plantio direto. Ci. Rural, v. 33, n. 6, p. 1161-1164, 2003.

COMORETTO, L. et al. Runoff of pesticides from rice fields in the Ile de Camargue (Rhône river delta, France): Field study and modeling. Environ. Pollution, v. 151, n. 3, p. 486-493, 2008.

CORNELISSEN, G. et al. Extensive sorption of organic compounds to black carbon, coal, and kerogen in sediments and soils: mechanisms and consequences for distribution, bioaccumulation, and biodegradation. Environ. Sci. Technol., v. 39, n. 18, p. 6881-6895, 2005.
CORREIA, F. V.; LANGENBACH, T. Dinâmica da distribuição e degradação de atrazina em argissolo vermelho-amarelo sob condições de clima tropical úmido. R. Bras. Ci. Solo, v. 30, n. 1, p. 183-192, 2006.

CRUZ, C. D. Programa Genes: biometria. Viçosa, MG: Universidade Federal de Viçosa, 2006. 382 p.

CRUZ, C. D.; FERREIRA, M. F.; PESSONI, L. A. Biometria aplicada ao estudo da diversidade genética. Viçosa, MG: Universidade Federal de Viçosa, 2011. $620 \mathrm{p}$.

DELGADO-MORENO, L.; PEÑA, A. Sorption/ desorption behaviour of sulfonylurea herbicides as affected by the addition of fresh and composted olive cake to soil. Weed Res., v. 48, n. 5, p. 461-469, 2008.

DUKE, S. O.; LYDON, J.; PAUL, R. N. Oxadiazon activity is similar to that of p-nitro-diphenyl ether herbicides. Weed Sci., v. 37, n. 2, p. 152-160, 1989.

ELIASON, R. et al. Phytotoxicity and persistence of flucarbazone-sodium in soil. Weed Sci., v. 52, n. 5, p. 857-862, 2004.

ESTÉVEZ, M. A. et al. The mobility and degradation of pesticides in soils and the pollution of groundwater resources. Agric. Ecosyst. Environ., v. 123, n. 4, p. 247-260, 2008.

FIRMINO, L. E. et al. Sorção do imazapyr em solos com diferentes texturas. Planta Daninha, v. 26, n. 2, p. 395402, 2008.

FOOTPRINT. Creating tools for pesticide risk assessment and management in Europe. University of Hertfordshire. Disponível em: <http://sitem.herts.ac.uk/ aeru/footprint/en/index.htm>. Acesso em: 21 janeiro 2013.

FOURIE, J. C. Herbigation in a Vineyard: persistence of four pre-emergence herbicides in a sandy loam soil. South Afr. J. Enol. Solo, v. 13, n. 2, p. 64-70, 1992.

FREITAS, S. P. et al. Efeitos de resíduos da suinocultura sobre a atividade do diuron aplicado ao solo. R. Ceres, v. 45, n. 62, p. 491-504, 1998.

GARBI, C. et al. Biodegradation of oxadiazon by a soil isolated Pseudomonas fluorescens strain CG5: Implementation in an herbicide removal reactor and modeling. Water Res., v. 40, n. 6, p. 1217-1223, 2006. 
GOMES, J.; DICK, D. P.; SOUZA, R. F. Sorção de atrazina em cambissolo húmico do Rio Grande do Sul sob vegetação nativa. R. Bras. Ci. Solo, v. 26, n. 2, p. 521-528, 2002.

GOSS, R. M.; GAUSSOIN, R. E.; MARTIN, A. R. Glyphosate rate-response of common turfgrass weeds. Inter. Turfgrass Soc. Res. J., v. 11, n. 2, p. 1191-1197, 2009.

HOQUE, M. E. et al. Sorption behaviour of oxadiazon in tropical rice soils. Water Sci. Technol., v. 56, n. 1, p. 115-121, 2007.

LEITE, L. F. C. et al. Estoques totais de C orgânico e seus compartimentos em argissolo sob floresta e sob milho cultivado com adubação mineral e orgânica.

R. Bras. Ci. Solo, v. 27, n. 5, p. 821-832, 2003.

LIMA, R. O. et al. Comportamento do herbicida flumioxazin em solo com diferentes doses de calcário. R. Ceres, v. 46, n. 268, p. 607-614, 1999.

LIN, Y. J. et al. Photodegradation of the herbicides butachlor and ronstar using natural sunlight and diethylamine. B. Environ. Contam. Toxicol., v. 64, n. 6, p. $780-785,2000$.

MARTINAZZO, R. et al. Sorção de atrazina e de mesotriona em latossolos e estimativa do potencial de contaminação. Química Nova, v. 34, n. 8, p. 1378-1384, 2011.

MOURE, M. P. et al. Effect of organic matter and iron oxides on quaternary herbicide sorption-desorption in vineyard-devoted soils. J. Colloid Inter. Sci., v. 333, n. 2, p. 431-438, 2009.

OLIVEIRA, M. F. et al. Sorção do herbicida imazaquin em latossolo sob plantio direto e convencional. Pesq. Agropec. Bras., v. 39, n. 8, p. 787-793, 2004.

OLIVEIRA, M. F.; PRATES, H. T.; SANS, L. M. A. Sorção e hidrólise do herbicida flazasulfuron.

Planta Daninha, v. 23, n. 1, p. 101-113, 2005.

PRATA, F.; LAVORENTI, A. Comportamento de herbicidas no solo: influência da matéria orgânica. R. Bioci., v. 6, n. 2, p. 17-22, 2000.

SEGNINI, A. et al. Estudo comparativo de métodos para a determinação da concentração de carbono em solos com altos teores de Fe (latossolos). Química Nova, v. 31, n. 1, p. 94-97, 2008.
SHENG, G. et al. Potential contributions of smectite clays and organic matter to pesticide retention in soils. J. Agric. Food Chem., v. 49, n. 6, p. 899-907, 2001.

SI, Y. et al. Influence of organic amendment on the adsorption and leaching of ethametsulfuron-methyl in acidic soils in China. Geoderma, v. 130, n. 1, p. 66-76, 2006.

SOUZA, A. P. et al. Efeito do oxyfluorfen, 2,4-D e glyphosate na atividade microbiana de solos com diferentes texturas e conteúdo de matéria orgânica.

Planta Daninha, v. 14, n. 1, p. 55-64, 1996.

STEINER, F. et al. Carbono orgânico e carbono residual do solo em sistema de plantio direto, submetido a diferentes manejos. R. Bras. Ci. Agr., v. 6, n. 3, p. 401-408, 2011.

SUN, K. et al. Assessment of herbicide sorption by biochars and organic matter associated with soil and sediment. Environ. Pollution, v. 163, n. 7, p. 167-173, 2012.

SZMIGIELSKA, A. M.; SCHOENAU, J. J.; GREER, K. Comparasion of chemical extraction and bioassay for measurement of metsulfuron in soil. Weed Sci., v. 46, n. 4, p. 487-493, 1998.

SZMIGIELSKI, A. M. et al. Development of a laboratory bioassay and effect of soil properties on sulfentrazone phytotoxicity in soil. Weed Technol., v. 23, n. 3, p. 486-491, 2009.

TAO, Q. H.; TANG, H. X. Effect of dye compounds on the adsorption of atrazine by natural sediment.

Chemosphere, v. 56, n. 1, p. 31-38, 2004.

XU, D. et al. Adsorption behavior of herbicide butachlor on typical soils in China and humic acids from the soil samples. J. Colloid Interface Sci., v. 285, n. 1, p. 27-32, 2005.

YING, G.; WILLIAMS, B. Laboratory study on the interaction between herbicides and sediments in water systems. Environ. Pollution, v. 107, n. 3, p. 399-405, 2000.

YING, G;; WILLIAMS, B. The degradation of oxadiazon and oxyfluorfen by photolysis. J. Environ. Sci. Health, Part B, v. 34, n. 4, p. 549-567, 1999. 